\title{
APPLICATION POTENTIAL OF SCREENING IN VITRO TOXICOLOGICAL ASSAYS IN QUALITATIVE RISK ASSESSMENT OF NANOMATERIALS
}

\author{
1,2Táňa ZÁVODNÁ, ${ }^{2}$ Jan TOPINKA, ${ }^{1,3}$ Pavel DANIHELKA \\ ${ }^{1}$ VŠB - Technical University of Ostrava, Faculty of Safety Engineering, Ostrava, Czech Republic, EU, \\ tana.brzicova@vsb.cz \\ 2Institute of Experimental Medicine, CAS, Prague, Czech Republic, EU, jan.topinka@iem.cas.cz \\ ${ }^{3}$ Occupational Research Safety Institute, Ostrava, Czech Republic, EU, danihelka@vubp-praha.cz \\ https://doi.org/10.37904/nanocon.2019.8687
}

\begin{abstract}
Undeniable benefits of engineered nanomaterials might be discredited by their potential enhanced or unexpected toxicity arising from nano-specific properties and behavior. An analysis of the applicability of the traditional chemical risk assessment approach in nanomaterials revealed high levels of uncertainty in both hazard characterization and exposure assessment due to the lack of relevant validated methods and reliable data. This indicates the limited capability of the conventional risk assessment approach to ensure the safe use of nanomaterials. Based on the identified uncertainties, the control banding approach was proposed as a suitable tool for preliminary qualitative risk assessment of nanomaterials in occupational settings. Control banding categorizes hazard and exposure into levels referred to as bands. The combination of the hazard and exposure bands results in a risk band determining the necessary degree of control and regulatory measures. To decrease the number of cases where, based on the precautionary principle, unavailable experimental or field data would lead to the assignment to the highest hazard category requiring costly exposure control, screening evaluation of nanomaterial toxicity was proposed as an additional decision criterion. For this purpose, a battery of in vitro toxicological assays enabling screening evaluation of potential toxic effects of NMs was proposed. The assays evaluate endpoints covering basic toxic effects of substances (cytotoxicity, genotoxicity), as well as known nonspecific mechanisms of toxicity typical for nanomaterials (oxidative stress, inflammation). The proposed risk management strategy is intended to assist small and medium-sized enterprises to implement adequate measures to ensure employee safety.
\end{abstract}

\section{INTRODUCTION}

Applications of nanomaterials (NMs) can significantly improve the quality of human ordinary life as well as contribute to solving major challenges that our society is currently facing. The development and applications of new NMs are crucial for progress and competitiveness in most industries. To ensure the safe use and sustainable development of any new technology, its potential risks must be understood and effectively controlled. Risk assessment is a science-based tool used for evaluation of potential adverse effects of chemicals under realistic exposure conditions.

NM variability, dynamic behavior dependent on the surrounding environment, and potentially unexpected toxic effects complicate the risk assessment and risk management. The standard risk assessment approach designed for classical chemical substances may not be suitable for NMs. In the present study, we analyzed the applicability of the conventional risk assessment in NMs. With regard to the identified high uncertainties in all steps of the process, we proposed an alternative approach - a qualitative risk assessment tool (control banding) and a set of in vitro toxicity assays for screening evaluation of NMs toxicity.

\section{ANALYSIS OF THE APPLICABILITY OF STANDARD RISK ASSESSMENT TOOLS FOR NMS}

Nano-specific exposure limits and quantitative risk assessment processes are not available. NMs are regulated by the same tools as classical chemicals, despite the fact that their behavior, toxicity, and safe exposure levels 
can significantly differ. First, we analyzed whether the traditional risk assessment approach for conventional chemicals can be applied in NMs with regards to their specific characteristics and behavior. Overall, it has been revealed that the process may be hindered by the lack of conclusive experimental data, unavailability of reliable standard methods, enormous variability of NMs and their dynamic behavior in the environment (see Table 1 for details). These factors lead to high uncertainties in all steps of the risk assessment process and the inability to set relevant exposure limits.

Table 1 Selected factors complicating the conventional risk assessment process

\begin{tabular}{|c|c|}
\hline NM characteristics & Why the conventional approach cannot be currently applied? \\
\hline $\begin{array}{l}\text { Absence of a unified } \\
\text { definition for NMs }\end{array}$ & $\begin{array}{l}\text { In has not been clearly established and agreed upon what should and what should not } \\
\text { be classified as a NM. The most common definition based on a cut-off size of } 100 \mathrm{~nm} \\
\text { does not have a scientific rationale [1]. }\end{array}$ \\
\hline Variability & $\begin{array}{l}\text { An extreme number of NM variants for assessment (time and economical costs for } \\
\text { testing all variants are unacceptable) [2]. }\end{array}$ \\
\hline $\begin{array}{l}\text { High number of physico- } \\
\text { chemical properties } \\
\text { affecting toxicity }\end{array}$ & $\begin{array}{l}\text { The complex action of a high number of physico-chemical properties on NM toxicity. } \\
\text { Time, economical and technically demanding characterization of NMs is a necessary } \\
\text { part of toxicity assessment. }\end{array}$ \\
\hline $\begin{array}{l}\text { Potential specific toxic } \\
\text { effects }\end{array}$ & $\begin{array}{l}\text { Standard methods do not exist to evaluate toxic effects that are not yet known (and } \\
\text { unexpected toxic effects may not be tested). }\end{array}$ \\
\hline $\begin{array}{l}\text { Non-existing } \\
\text { epidemiological data }\end{array}$ & $\begin{array}{l}\text { Information on NM toxic effects in humans (including toxicokinetics) is not available for } \\
\text { most NMs. }\end{array}$ \\
\hline NM heterogeneity & $\begin{array}{l}\text { NMs are usually not homogeneous, e.g. size distribution of (nano) particles in a sample } \\
\text { (polydispersity). }\end{array}$ \\
\hline $\begin{array}{l}\text { Inconsistency of } \\
\text { experimental data }\end{array}$ & $\begin{array}{l}\text { A solid conclusion on NM toxicity cannot be derived based on inconsistent or even } \\
\text { contradictory experimental data (high inter- and intra-laboratory variability of results). }\end{array}$ \\
\hline Dosimetry is not clear & $\begin{array}{l}\text { No agreement on what dose unit is most relevant for describing toxic effects of NMs } \\
\text { (surface area, particle number, volume, and surface reactivity have been suggested in } \\
\text { addition to the traditionally used mass concentration that is most probably not a suitable } \\
\text { dose metric for NMs) [3]. }\end{array}$ \\
\hline Different toxicokinetics & $\begin{array}{l}\text { Extrapolation of the toxic effects from experimental animals to humans is problematic } \\
\text { due to different translocation to secondary organs, different hot spots (accumulation } \\
\text { areas in the organism), different capabilities of NM elimination [4] }\end{array}$ \\
\hline $\begin{array}{l}\text { Dynamic behavior in the } \\
\text { environment }\end{array}$ & $\begin{array}{l}\text { Primary NMs have different properties than aged NMs present in the environment. } \\
\text { Similarly, NMs tested under laboratory conditions may have different properties than } \\
\text { NMs released into the environment. The formation and composition of biocorona } \\
\text { depend on the biological environment [5]. }\end{array}$ \\
\hline In vitro dosimetry & $\begin{array}{l}\text { Specific NM behavior in in vitro assays - sedimentation, (de)agglomeration, dissolution, } \\
\text { adhesion on laboratory plastics. The real dose to which the treated biological system is } \\
\text { exposed may differ from the administered dose [6]. }\end{array}$ \\
\hline $\begin{array}{l}\text { Specific physico-chemical } \\
\text { properties }\end{array}$ & $\begin{array}{l}\text { Interference with in vitro toxicological methods. Specific NM properties can lead to } \\
\text { false-negative/false-positive results, and under-/overestimation of toxicity [7]. }\end{array}$ \\
\hline Variability in batches & $\begin{array}{l}\text { A slight change in the production process, storage conditions or handling can modify } \\
\text { NM properties (and consequently toxicity). }\end{array}$ \\
\hline
\end{tabular}

\section{CONTROL BANDING AS A QUALITATIVE RISK MANAGEMENT TOOL FOR NMS}

The basic principle of risk assessment consisting of hazard assessment (i.e. identification of possible hazard and its quantification) and exposure assessment (i.e. estimation or measurement ofhe magnitude, frequency, and duration of exposure) is also applicable for substances with high uncertainty data. In this case, qualitative methods employing the precautionary principle are more suitable than quantitative approaches (see Figure 1A).

Control Banding $(\mathrm{CB})$ was selected as a suitable qualitative risk management tool for NMs when reliable experimental data are not available. CB tools are developed by experts on chemical safety to be used in small- 
and medium-sized enterprises without an on-site expert on occupational health and safety to control workers' exposure to potentially dangerous substances. CB categorizes hazard and exposure into bands based on input data related to toxic and emission potentials. The combination of the hazard and exposure bands results in a risk band determining the necessary degree of control and regulatory measures (Figure 1B). CB tools developed for NMs and their main characteristics are summarized in Table 2.

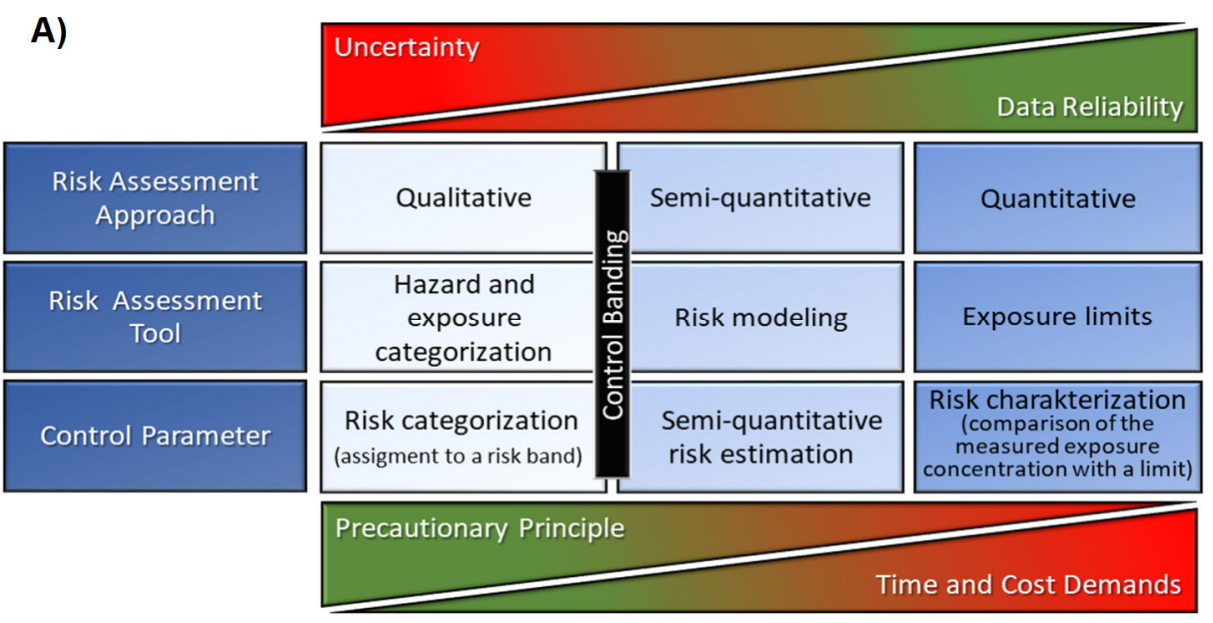

B)

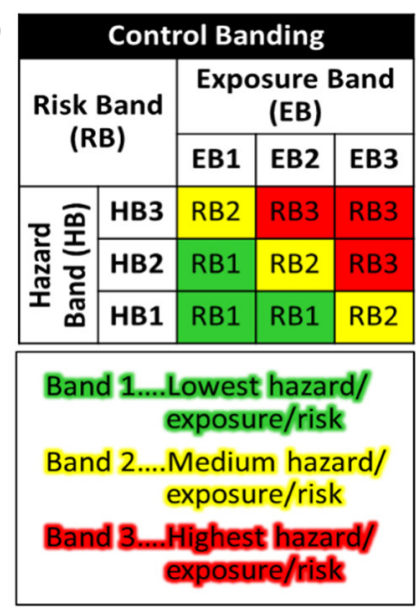

Figure 1 A) Risk assessment approaches classified according to data availability and the level of uncertainty B) Principle of Control Banding as a qualitative risk assessment tool

Table 2 Control Banding Tools for NMs

\begin{tabular}{|c|c|c|c|c|c|c|c|}
\hline $\begin{array}{l}\overline{8} \\
\stackrel{8}{0} \\
0 \\
0\end{array}$ & 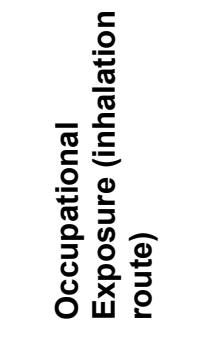 & 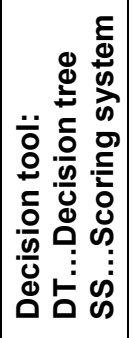 & 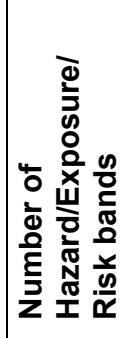 & 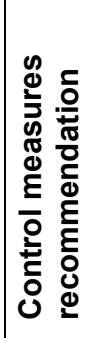 & 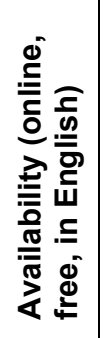 & 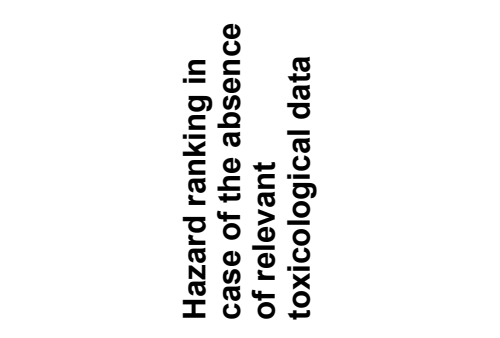 & 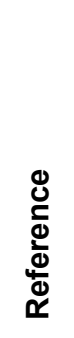 \\
\hline ANSES CB Tool & YES & DT & $5 / 4 / 5$ & YES & YES & Ask an experienced toxicologist & [9] \\
\hline CB NanoTool & $\begin{array}{l}\text { Research } \\
\text { laboratories }\end{array}$ & SS & $4 / 4 / 4$ & YES & YES & $75 \%$ of the maximal score & [10] \\
\hline ISO/TS 120901-2:2014 & YES & DT & $5 / 4 / 4$ & YES & YES & $\begin{array}{c}\text { Categorized in the highest hazard } \\
\text { band }\end{array}$ & [8] \\
\hline IVAM Guidance & YES & DT & $3 / 3 / 3$ & YES & YES & $\begin{array}{l}\text { Only information on solubility and } \\
\text { fibrous shape is required }\end{array}$ & [11] \\
\hline LICARA nanoSCAN & $\begin{array}{l}\text { YES (for new } \\
\text { products) }\end{array}$ & DT, SS & $5 / 4 / 3$ & NO & YES & $\begin{array}{l}\text { Categorized in the highest hazard } \\
\text { band }\end{array}$ & [12] \\
\hline NanoRiskCat & $\begin{array}{c}\text { Consumer } \\
\text { safety }\end{array}$ & DT & $4 / 4 /-$ & NO & YES & Evaluated as "unknown hazard" & [13] \\
\hline NanoSafer & YES & DT, SS & $4 / 5 / 5$ & YES & YES & $\begin{array}{l}\text { Information on bulk analoque is } \\
\text { required }\end{array}$ & [14] \\
\hline $\begin{array}{l}\text { Precautionary Matrix } \\
\text { for synthetic materials }\end{array}$ & YES & SS & $3 / 3 / 2$ & NO & YES & $\begin{array}{c}\text { Categorized in the highest hazard } \\
\text { band }\end{array}$ & [15] \\
\hline Stoffenmanager Nano & YES & DT, SS & $5 / 4 / 3$ & YES & YES & $\begin{array}{l}\text { Categorized in the highest hazard } \\
\text { band }\end{array}$ & [16] \\
\hline
\end{tabular}




\subsection{In vitro toxicological assays as a screening tool for hazard ranking in CB risk assessment of NMs}

In the absence of reliable toxicological data, the majority of control banding tools employ the precautionary principle by assignment the NM to the highest hazard band, requiring a strict exposure control to reach an acceptable risk band (see Table 2). This conservative approach may pose an unnecessary burden for smalland medium-sized enterprises in case of NMs with low toxicity where, however, no reliable experimental data are currently available. For a more accurate hazard categorization of these NMs, we propose a battery of simple in vitro toxicological assays. The assay battery (see Figure 2) reflects current knowledge on the mechanisms of NM toxicity and takes into account suitability of methods for testing NMs. It comprises of four endpoints covering basic toxic effects of substances (cytotoxicity and genotoxicity) and known non-specific toxic effects typical for NMs (oxidative stress, pro-inflammatory effects). Assay protocols can be obtained from manufacturers and EU nanosafety/nanotoxicology-oriented projects (e.g. NANOGENOTOX, NANOMMUNE, NANOVALID, QUALITYNANO, etc.).

The basic conditions for testing are proposed as follows:

- Biological system - Macrophages: Comparative studies have shown that macrophages (effector cells of the innate immune system) are among the most sensitive cell types towards NM toxicity [17]. In an organism, macrophages are one of the first cells that are encountered by inhaled NMs.

- Tested concentrations $-1,10,100 \mu \mathrm{g} / \mathrm{ml}$ : A minimum of three concentrations is needed to construct a dose-response curve. The highest recommended concentration is $100 \mu \mathrm{g} / \mathrm{ml}$, lower concentrations were derived from a logarithmic range. Non-cytotoxic concentrations (i.e. viability $>70 \%$ ) should be used in testing genotoxicity, oxidative potential, and pro-inflammatory effects.

- $\quad$ Exposure time - 24h: 24 hours is the most often used exposure period in in vitro nanotoxicology as it is the time that fast proliferating cells need to go through one cell cycle.

\begin{tabular}{|c|c|c|c|c|c|c|c|c|}
\hline \multirow[b]{2}{*}{ Hazard } & \multirow[b]{2}{*}{$\begin{array}{l}\text { Evaluation } \\
\text { method }\end{array}$} & \multirow[b]{2}{*}{ Marker } & \multirow[b]{2}{*}{$\begin{array}{l}\text { Expression } \\
\text { of results }\end{array}$} & \multicolumn{3}{|c|}{ Hazard categorization } & \multirow[b]{2}{*}{$\begin{array}{l}\text { Marker } \\
\text { Weight }\end{array}$} & \multirow{2}{*}{$\begin{array}{l}\text { Critical } \\
\text { Values }\end{array}$} \\
\hline & & & & $\begin{array}{c}\text { Score } \\
=0\end{array}$ & $\begin{array}{l}\text { Score } \\
=1\end{array}$ & $\begin{array}{l}\text { Score } \\
=2\end{array}$ & & \\
\hline \multirow{2}{*}{ 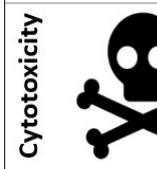 } & \multirow{2}{*}{$\begin{array}{l}2 \text { independent } \\
\text { assays } \\
\longrightarrow \text { ATP }\end{array}$} & $\begin{array}{l}\text { Metabolic activity } \\
\text { (mitochondria) }\end{array}$ & $\mathrm{LC}_{30}(\mu \mathrm{g} / \mathrm{ml})$ & $>100$ & $\begin{array}{l}>10 \\
<100\end{array}$ & $<10$ & 2 & $\mathrm{LC}_{50}<10 \mu \mathrm{g} / \mathrm{ml}$ \\
\hline & & $\begin{array}{l}\text { Metabolic activity } \\
\text { (ATP production) }\end{array}$ & $\mathrm{LC}_{30}(\mu \mathrm{g} / \mathrm{ml})$ & $>100$ & $\begin{array}{l}>10 \\
<100\end{array}$ & $<10$ & 2 & $\mathrm{LC}_{50}<10 \mu \mathrm{g} / \mathrm{ml}$ \\
\hline \multirow{3}{*}{ 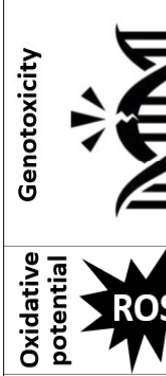 } & \multirow{2}{*}{$\begin{array}{l}\text { FPG+ } \\
\text { Comet assay } \\
\text { (alkaline version) } \\
\text { FPG- }\end{array}$} & DNA breaks & $\begin{array}{l}\% \text { damaged (tail) DNA (increase } \\
\text { compared to NC median values) }\end{array}$ & $<1.5$ & $\begin{array}{l}>1.5 \\
<10\end{array}$ & $>10$ & 2 & $\begin{array}{l}>5 \text { at a } \\
\text { concentration } \\
\text { of } 1 \mu \mathrm{g} / \mathrm{ml}\end{array}$ \\
\hline & & $\begin{array}{l}\text { Oxidative DNA } \\
\text { damage }\end{array}$ & $\begin{array}{l}\% \text { damaged (tail) DNA after DNA } \\
\text { breaks substraction (increase } \\
\text { compared to NC median values) }\end{array}$ & $<1.5$ & $\begin{array}{l}>1.5 \\
<10\end{array}$ & $>10$ & 2 & $\begin{array}{l}>5 \text { at a } \\
\text { concentration } \\
\text { of } 1 \mu \mathrm{g} / \mathrm{ml}\end{array}$ \\
\hline & DCFDA & ROS production & Increase compared to NC & $<1.2$ & $\begin{array}{l}>1.2 \\
<2\end{array}$ & $>2$ & 2 & $\begin{array}{l}>2 \text { at a } \\
\text { concentration } \\
\text { of } 1 \mu \mathrm{g} / \mathrm{ml}\end{array}$ \\
\hline \multirow{2}{*}{ 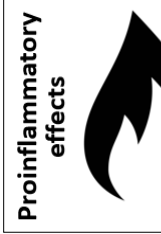 } & \multirow{2}{*}{${ }_{\mathrm{IL}-8}^{\mathrm{IL}-6}$} & $\begin{array}{l}\text { Inflammatory } \\
\text { cytokine } \\
\text { production }\end{array}$ & $\begin{array}{l}\text { Increase compared to NC } \\
\text { (for each cytokine) }\end{array}$ & $<1.2$ & $\begin{array}{l}>1.2 \\
<2\end{array}$ & $>2$ & $\begin{array}{l}1 \\
1 \\
1\end{array}$ & $\begin{array}{l}>2 \text { at a } \\
\text { concentration } \\
\text { of } 1 \mu \mathrm{g} / \mathrm{ml}\end{array}$ \\
\hline & & $\begin{array}{l}\text { Chemokine } \\
\text { production }\end{array}$ & Increase compared to NC & $<1.2$ & $\begin{array}{l}>1.2 \\
<2\end{array}$ & $>2$ & 1 & $\begin{array}{l}>2 \text { at a } \\
\text { concentration } \\
\text { of } 1 \mu \mathrm{g} / \mathrm{ml}\end{array}$ \\
\hline
\end{tabular}

Figure 2 The selected endpoints and in vitro assays for screening evaluation of NM toxicity within CB 


\section{Evaluation of the results (see Figure 2)}

1) Green column - negative results (score $=0$ )

- Cytotoxicity: LC30 (lethal concentration that cause death of $30 \%$ cells) $>100 \mu \mathrm{g} / \mathrm{ml}$

- Genotoxicity: more than 1.5 fold increase compared to negative control (NC) values

- Oxidative potential and proinflammatory effects: more than 1.2 fold increase compared to NC values (takes into account generally accepted $20 \%$ variability in biological assays [18])

2) Red column - positive results (score $=2$ )

- Cytotoxicity: LC30 $<10 \mu \mathrm{g} / \mathrm{ml}$

- Genotoxicity: more than 10 fold increase compared to NC median values

- Oxidative potential and proinflammatory effects: more than 2 fold increase compared to NC median values

3) Orange column - mild positivity (score $=1$ )

- Values between positive and negative results

\section{Hazard categorization}

1) Hazard band is assigned according to the total score calculated as a sum of all markers values multiplied by the marker weight

- $\quad$ Total score $\leq 4 \rightarrow \mathrm{HB} 1$

- $\quad$ Total score between 5 and $11 \rightarrow \mathrm{HB} 2$

- Total score $\geq 12 \rightarrow \mathrm{HB} 3$

2) Reaching 12 points during the sequential testing (cytotoxicity $\rightarrow$ genotoxicity $\rightarrow$ oxidative potential $\rightarrow$ proinflammatory effects) assigns the tested NM to HB3 and testing is discontinued.

3) Exceeding critical values (yellow column) - an indication of high toxicity at low concentrations

- Genotoxicity, oxidative potential, and proinflammatory effects: concentration $1 \mu \mathrm{g} / \mathrm{ml}$ is derived from estimations of the amount of nanoparticles to which cells in the lower respiratory tract can be exposed under high yet realistic air concentrations $[19,20]$.

- Cytotoxicity: a higher critical concentration $(10 \mu \mathrm{g} / \mathrm{ml})$ was set as cell death is a consequence of serious disturbance of cell functions and indicates adverse effects at lower concentrations.

\section{CONCLUSION}

The immense potential of NMs in theoretically all fields can be hindered by poorly controlled risks associated with their production, applications, and use. Analysis of the applicability of the traditional risk assessment approach for conventional chemicals in NMs showed a high level of uncertainty in all steps of the process due to inconclusive experimental data, unavailability of reliable standard methods, enormous variability of NMs and their dynamic behavior in the environment. Under these circumstances (when no reliable nano-specific exposure limits can be set), qualitative risk assessment methods are a promising alternative. CB based on categorization and the precautionary principle was selected as a suitable interim tool for risk assessment of NMs. However, this conservational approach tends to overestimate risk in the absence of hard experimental data. For more accurate hazard classification, we propose a battery of simple in vitro toxicological assays. The assays cover 4 endpoints: cytotoxicity as a basic toxic parameter, genotoxicity as an important regulatory parameter due to its close relationship with carcinogenicity, oxidative potential as a main known mechanism of NM toxicity, and inflammation as immune-mediated effects. The assay battery can also be used to compare the toxicity of NMs with different physico-chemical properties and to prioritize less toxic variants with the aim to minimize investment into the development of NMs with low application potential. CB is an interim solution and the risk assessment approach should be updated based on new scientific findings. 


\section{ACKNOWLEDGEMENTS}

Supported by the MEYS CR (LO1508; LM2015073; CZ.02.1.01/0.0/0.0/16_013/0001821).

\section{REFERENCES}

[1] SCENIHR, EC. Scientific Basis for the Definition of the Term "nanomaterial". European Commission, Scientific Committee on Emerging and Newly Identified Health Risks (SCENIHR). 2010.

[2] CHOI, Jae-Young; RAMACHANDRAN, Gurumurthy; KANDLIKAR, Milind. The impact of toxicity testing costs on nanomaterial regulation. Environmental Science \& Technology. 2009. vol. 43, no. 9, pp. 3030-3034.

[3] DONALDSON, K., et al. Concordance between in vitro and in vivo dosimetry in the proinflammatory effects of lowtoxicity, low-solubility particles: the key role of the proximal alveolar region. Inhalation Toxicology. 2008. vol. 20, no. 1 , pp. 53-62.

[4] KREYLING, Wolfgang G., et al. Differences in the biokinetics of inhaled nano-versus micrometer-sized particles. Accounts of Chemical Research. 2012. vol. 46, no. 3, pp. 714-722.

[5] NEAGU, Monica, et al. Protein bio-corona: critical issue in immune nanotoxicology. Archives of toxicology. 2017. vol. 91, no. 3, pp. 1031-1048.

[6] COHEN, Joel, et al. Interactions of engineered nanomaterials in physiological media and implications for in vitro dosimetry. Nanotoxicology. 2013. vol. 7, no. 4, pp. 417-431.

[7] GUADAGNINI, Rina, et al. Toxicity screenings of nanomaterials: challenges due to interference with assay processes and components of classic in vitro tests. Nanotoxicology. 2015. vol. 9, sup1, pp. 13-24.

[8] ISO (INTERNATIONAL ORGANIZATION FOR STANDARDIZATION). Nanotechnologies -- Occupational risk management applied to engineered nanomaterials -- Part 2: Use of the control banding approach, ISO/TS 129012:2014

[9] RIEDIKER, Michael, et al. Development of a control banding tool for nanomaterials. Journal of Nanomaterials. 2012. vol. 2012, no. 8.

[10] ZALK, David M.; PAIK, Samuel Y.; SWUSTE, Paul. Evaluating the control banding nanotool: a qualitative risk assessment method for controlling nanoparticle exposures. Journal of Nanoparticle Research. 2009. vol. 11, no. 7, pp. 1685.

[11] CORNELISSEN, Ralf, I. V. A. M. Guidance working safely with nanomaterials and-products, the guide for employers [online]. Industox (C2011 [cit. 11. 9. 2019]. Dostupné z: http://www.industox.nl/Guidance\%20on\%20safe\%20handling\%20nanomats\&products.pdf

[12] VAN HARMELEN, Toon, et al. LICARA nanoSCAN-A tool for the self-assessment of benefits and risks of nanoproducts. Environment Intrenational. 2016. vol. 91, pp. 150-160.

[13] HANSEN, Steffen Foss; JENSEN, Keld Alstrup; BAUN, Anders. NanoRiskCat: a conceptual tool for categorization and communication of exposure potentials and hazards of nanomaterials in consumer products. Journal of Nanoparticle Research. 2014. vol. 16, no. 1, pp. 2195.

[14] JENSEN, Keld A., et al. NanoSafer vs. 1.1-nanomaterial risk assessment using first order modeling. In: 6th International Symposium on Nanotechnology, Occupational and Environmental Health. 2013.

[15] HÖCK, J., et al. Precautionary matrix for synthetic nanomaterials. Berne, Switzerland, Swiss Federal Office of Public Health and Federal Office for the Environment. 2008.

[16] VAN DUUREN-STUURMAN, Birgit, et al. Stoffenmanager nano version 1.0: a web-based tool for risk prioritization of airborne manufactured nano objects. Annals of Occupational Hygiene. 2012. vol. 56, no. 5, pp. 525-541.

[17] FARCAL, Lucian, et al. Comprehensive in vitro toxicity testing of a panel of representative oxide nanomaterials: first steps towards an intelligent testing strategy. PLoS One. 2015. vol. 10, no. 5, pp. e0127174.

[18] ANDREASSON, Ulf, et al. A practical guide to immunoassay method validation. Frontiers in neurology. 2015. vol. 6., pp. 179.

[19] GANGWAL, Sumit, et al. Informing selection of nanomaterial concentrations for ToxCast in vitro testing based on occupational exposure potential. Environmental health perspectives. 2011. vol. 119, no. 11, pp. 1539-1546.

[20] OBERDÖRSTER, Günter. Nanotoxicology: in vitro-in vivo dosimetry. Environmental Health Perspectives. 2012. vol. 120 , no. 1 , pp. a13-a13. 